\title{
2q31.1 microdeletion syndrome
}

INSERM

\section{Source}

INSERM. (1999). Orphanet: an online rare disease and orphan drug data base. 2 q31.1 microdeletion syndrome. ORPHA:251014

2q31.1 microdeletion syndrome is a well-defined and clinically recognisable syndrome characterized by moderate to severe developmental delay, short stature, facial dysmorphism and variable limb defects. 